\title{
NEUROMUSCULAR TAPING INCREASES MUSCLE STRENGTH, FLEXIBILITY, AND SHORTEN THE 100 METER SPRINTER TRAVEL TIME
}

\author{
Agung Hadi Endaryanto ${ }^{1 *}$, Elyana Asnar ${ }^{2}$, Roostantia Indrawati ${ }^{3}$ \\ ${ }^{1}$ Master of Sport Health Science, Faculty of Medicine, Universitas Airlangga, Surabaya, Indonesia ${ }^{2}$ Department of \\ Physiology, Faculty of Medicine, Universitas Airlangga, Surabaya, Indonesia ${ }^{3}$ Department of Pharmacology, \\ Faculty of Medicine, Universitas Airlangga, Surabaya, Indonesia.
}

\begin{abstract}
Sprint or short distance run is one of the most prestigious athletic numbers. The runner is called sprinter. NMT is an application technique that uses elastic adhesive tape that provides enhanced muscle functional ability and nervous system stimulation. The purpose of this study was to determine the influence of neuromuscular taping on muscle strength, muscle flexibility and travel time of 100 meter sprinter. This study used pre test-post test method control group design with total sample of 13 people with age range of 15-19 years. This study conducted on 4-5 August 2016 at GOR Gresik. Group 1 received 2 treatments. In the first treatment, before receiving NMT, muscle strength, muscle flexibility, and running time for 100 meter were measured. In the second treatment, the measurement were repeated after receiving NMT. Treatment group 2 as control group received no NMT and subjected to the measurement of muscle strength, muscle flexibility, and running time of 100 meters. The results showed that gastrocnemius muscle strength was increased by $11.38 \pm 7.83 \mathrm{~kg}, P=0.000, P=0.003$ (dorsiflexion), $P=0.013$ (plantarflexion) with mean improvement $3.46 \pm 4.27$ degrees, and shortening of travel time with $p$ value $=0.001$. In group 2, the gastrocnemius muscle strength was found to have a mean decrease of $2.12 \pm 2.43 \mathrm{~kg}, P=0.009$, flexibility $P=1.000$ (dorsiflexion), $P=0.165$ (plantarflexion) with an average increase of $0.77 \pm 1.88$ degrees, and the running time extension had a $P$ of 0.001 . Providing NMT to the sprinter gives better results in increased muscle strength, muscle flexibility and shortening travel time.
\end{abstract}

Keywords: neuromuscular taping (NMT); sprinter; performance

\section{ABSTRAK}

Lari sprint atau lari jarak pendek adalah salah satu nomor dalam atletik yang paling bergengsi, pelarinya disebut Sprinter. NMT adalah tehnik aplikasi yang menggunakan elastic adhesif tape yang memberikan kemampuan peningkatan fungsional otot, dan stimulasi sistem saraf. Tujuan penelitian ini, untuk mengetahui pengaruh neuromuscular taping terhadap kekuatan otot, fleksibilitas otot dan waktu tempuh sprinter adalah 100 meter. Penelitian ini menggunakan metode pre test-post test with control grup design dengan total sampel berjumlah 13 orang dengan rentang usia atlet 15-19 tahun, pada tanggal 4-5 Agustus 2016 di GOR Gresik. Metode 1 kelompok dengan 2 perlakuan yaitu perlakuan I sebelum pemberian NMT dilakukan pengukuran kekuatan otot, fleksibilitas otot, dan waktu tempuh berlari 100 meter dan sesudah pemberian NMT dilakukan pengukuran kembali, perlakuan 2 sebagai kelompok kontrol dilakukan tanpa pemberian NMT dilakukan pengukuran kekuatan otot, fleksibilitas otot, dan waktu tempuh berlari 100 meter. Hasil penelitian menunjukkan pada perlakuan 1 kekuatan otot gastrocnemius dengan peningkatan rerata $11,38 \pm 7,83 \mathrm{~kg}, P=0,000$, fleksibilitas nilai $P=0,003$ (dorsiflexion), $P=0,013$ (plantarflexion) dengan peningkatan rerata 3,46 $\pm 4,27$ derajat, dan pemendekan waktu tempuh dengan nilai $P=0,001$, pada perlakuan 2 kekuatan otot gastrocnemius dengan penurunan rerata 2,12 $\pm 2,43 \mathrm{~kg}$, nilai $P=0,009$, fleksibilitas nilai $P=1,000$ (dorsiflexion), $P=0,165$ (plantarflexion) dengan peningkatan rerata 0,77 $\pm 1,88$ derajat, dan waktu tempuh terjadi perpanjangan waktu dengan nilai $P=0,001$. Pemberian NMT pada sprinter memberikan hasil yang lebih baik dalam peningkatan kekuatan otot, fleksibilitas otot dan memperpendek waktu tempuh.

Kata kunci: neuromuscular taping (NMT); sprinter; performa

Correspondence: Agung Hadi Endaryanto, Sport Health Science Master Program, Faculty of Medicine, Universitas Airlangga, Surabaya, Indonesia. E-mail: agung.he.ft@gmail.com

pISSN:2355-8393 • eISSN: 2599-056x • doi: 10.20473/fmi.v57i1.26329

- Fol Med Indones. 2020;57:16-19 • Received 9Jun 2018 • Accepted 15 Aug 2018

- Open access under CC-BY-NC-SA license • Available at https://e-journal.unair.ac.id/FMI/ 


\section{INTRODUCTION}

The history of taping therapy started from the development of bandaging techniques originating from Greece and Roman times. During the last 30 years, there arose the development of bandaging techniques that used non elastic and elastic techniques in different methods with the same concept. Not until 1970, the new techniques emerging that is used in sports is the use of elastic adhesive tape with various pull levels. In 2003, an Australian acupuncturist David Blow developed a neuromuscular taping technique of decompression and compression which is another type of taping and bandaging, called Neuromuscular Taping Concept (NMT). Neuro Muscular Taping (NMT) Concept is a biomechanical handling methodology using compression and decompression stimulation which has benefits on the musculoskletal, vascular, lymphatic, and human nervous system (Blow 2012). NMT's study after its introduction in 2003 until now is more on rehabilitation cases in both sports and clinical cases, while research on improving sports performance has not been widely available.

Running is one of the numbers in athletics competed; the distance varies, and one of the most anticipated and most prestigious sprints or short-range runs. Sprint is running at full speed along the distance that must be traveled to a predetermined distance. The runner can also be called sprinter. When viewed from the stages of the run, sprint consists of reactions and drives, acceleration, transition, speed maximum, maintenance speed and finish. It is all kind of run from start to finish and completed with maximum speed (Suharno 1993). Physical components required in short range run are durability, strength, speed, explosive power, flexibility, reaction time balance, agility, precision and reaction. Speed (movement) is the ability to perform a recurring activity that is the same and continuous in the shortest time (Nala 2011). Speed is a highly difficult physical ability. The increased exclusive training results only increased by $10 \%$. It means that to increase the best time record 100 meters run within 10 seconds or more than 10 seconds, it takes hard training. A speed depends on several factors that influence strength, reaction time and flexibility (Harsono 1988).

NMT (Neuromuscular Taping) is an application technique that uses adhesive elastic adhesive tape attached to the skin, resulting in a local therapeutic effect and directly affecting the reflex pathway with good results. The use of NMT will provide enhanced muscle functional ability by stimulating the response of the nervous system through biochemical, emotional, and energy stimulation mechanisms to achieve desired results. The installation of NMT is combined with movement activation in the taping area so as to stimulate some skin receptors and underlying tissue. The stimulation of these receptors will send exteroceptive and proprioceptive stimulation that will be sent to the central nervous system (Blow 2012). The mechanism of stimulation is obtained through mechanoreseptor and thermoreceptor obtained from changes in pressure, temperature, and movement (longshort) muscles carried through type 1a, 1b, II, and IV nerve fibers (Hall \& Guyton 2011). Giving NMT is expected to improve the functional ability of muscles both from strength and flexibility to increase the speed and shorten the travel time of 100 meter sprint athletes, both in training programs and competitions.

\section{MATERIALS AND METHODS}

This study was field experiment using pretest and posttest with control group design. This study used 1 group method with 2 treatments. Treatment 1 was done before neuromuscular taping which consisted of muscle strength measurement, muscle flexibility, and travel time run 100 meter and after giving neuromuscular taping measured muscle strength, muscle flexibility, and travel time 100 meter. Meanwhile, treatment 2 as a control group performed without neuromuscular taping performed muscle strength measurements, muscle flexibility, and travel time ran 100 meters. The subjects of the study were 100 meter sprinter athletes amounted to 13 people with the age of 15-19 years. The tape application was cut by the length measured from the gastrocnemius insertio on the heel (os calcaneus) to the length of the popliteal fossa margin. After cutting the length of the tape was made a model piece ' $Y$ ' with the base base or branching on the branching of the gastrocnemius muscle, the position at which the ankle was mounted in the dorsiflexion position 150 .

Figure 1. NMT application on gastrocnemius muscle

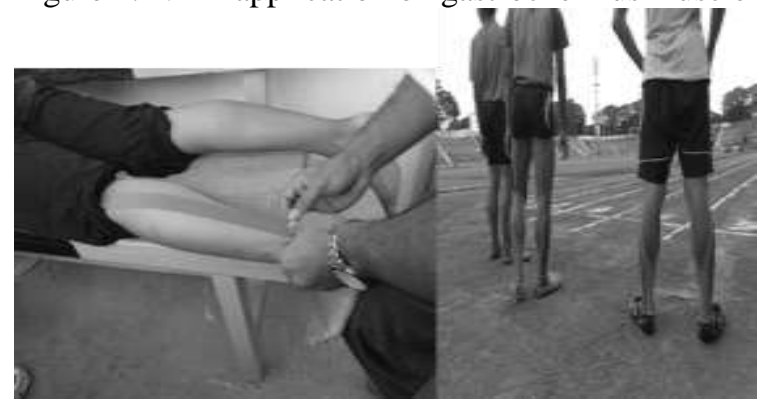

\section{RESULTS}

In the test results of pretest and posttest differences on the treatment 1 and 2 obtained some following results.

Table 1. Treatment 1 (experiments) 


\begin{tabular}{|c|c|c|c|}
\hline \multirow{2}{*}{ Variable } & \multicolumn{3}{|c|}{ Average \pm SD } \\
\hline & \multicolumn{2}{|l|}{ Pre } & Post \\
\hline Strngth (kg) & \multicolumn{2}{|c|}{$55 \pm 24,90$} & $66,39 \pm 24,23$ \\
\hline Dorsofleksi $\left({ }^{0}\right)$ & \multicolumn{2}{|c|}{$20 \pm 6,12$} & $23,46 \pm 4,27$ \\
\hline Plantar fleksi $\left({ }^{0}\right)$ & \multicolumn{2}{|c|}{$55,38 \pm 7,49$} & $58,85 \pm 5,46$ \\
\hline $\begin{array}{l}\text { Travel time } \\
\text { (second) }\end{array}$ & \multicolumn{2}{|c|}{$14,22 \pm 1,70$} & $14,03 \pm 1,76$ \\
\hline Variable & & Average \pm SD & $\mathrm{p}$ value \\
\hline \multicolumn{4}{|c|}{ Strength of Gastrocnemius } \\
\hline \multicolumn{2}{|l|}{ Muscle (kg) } & $11,38 \pm 7,83$ & 0,000 \\
\hline \multicolumn{2}{|c|}{ Dorsofleksi Flexibility $\left({ }^{0}\right)$} & & 0,003 \\
\hline \multicolumn{2}{|c|}{ Plantarfleksi Flexibility $\left({ }^{0}\right)$} & $3,46 \pm 4,27$ & 0,013 \\
\hline \multicolumn{2}{|c|}{ Travel Time (second) } & & 0,001 \\
\hline
\end{tabular}

Notes: Significant when alpha was $<0.05$

The results of statistical tests on gastrocnemius muscle strength and plantarflexion flexibility used paired t test, because the two variables were normal data distribution, while the flexibility of dorsiflexion and the time of data distribution was not normal. Based on the results of data on gastrocnemius muscle strength, dorsiflexion flexibility, and plantarflexion flexibility increased, while in time occurred shortening time between pre and post treatment, whereas in the $\mathrm{p}$ value obtained in all variables both gastrocnemius muscle strength, flexibility dorsiflexion, plantarflexion and travel time had found a significant difference.

Table 2. Treatment 2 (control)

\begin{tabular}{lll}
\hline \multirow{2}{*}{ Variable } & Average \pm SD & \\
\cline { 2 - 3 } & Pre & Post \\
\hline Strength (kg) & $47,27 \pm 21,52$ & $45,15 \pm 19,91$ \\
Dorsofleksi $\left(^{0}\right)$ & $20 \pm 6,12$ & $20 \pm 6,12$ \\
Plantarfleksi $\left({ }^{0}\right)$ & $55 \pm 7,64$ & $55,77 \pm 7,60$ \\
Travel Time (second) & $14,19 \pm 1,67$ & $14,42 \pm 1,76$ \\
\hline & & \\
\hline & & p value \\
\hline Variable & Average \pm SD & 0,009 \\
Strength of & $2,12 \pm 2,43$ & 1,000 \\
Gastrocnemius & & 0,165 \\
Muscle (kg) & $0,77 \pm 1,88$ & 0,001 \\
Dorsofleksi & & \\
Flexibility (0) & \\
Plantarfleksi & & \\
Flexibility (0) & & \\
Travel Time (second) & & \\
\hline
\end{tabular}

Notes: Significant when alpha was $<0.05$

The results of statistical tests on gastrocnemius muscle strength and plantarflexion flexibility using paired $t$ test, because the two variables were normal data distribution, while the flexibility of dorsiflexion and the time of data distribution was not normal. In the strength of the gastrocnemius muscle, there was a decrease in strength with $p$ value which indicated that there was a significant difference. In the flexibility of dorsiflexion, there was no difference, and there was a slight degree increase with the value of $\mathrm{p}$ which showed no significant difference on the flexibility of plantarflexion. Meanwhile, on the travel time, there was an elongation of travel time with $\mathrm{p}$ values which indicated significant differences.

Table 3. Test of treatment differentials 1 and 2 based on pre and post differences (delta)

\begin{tabular}{lll}
\hline Variable & Mean & SD \\
\hline Strngth_Control & $-2,1154$ & 2,43374 \\
Dorso_Control &, 0000 &, 00000 \\
Plantar_Control &, 7692 & 1,87767 \\
Travel time_Control &, 2277 &, 13405 \\
Strengh_Eksperiment & 11,3846 & 7,83463 \\
Dorso_Eksperiment & 3,4615 & 2,40192 \\
Plantar_Eksperiment & 3,4615 & 4,27425 \\
Travel time_Eksperiment &,- 1892 &, 20267 \\
\hline & \multicolumn{2}{|}{ P value } \\
\hline Variable $\Delta$ & 0,000 & \\
\hline Strength & 0,000 & \\
Dorsofleksi & 0,067 & \\
Plantarfleksi & 0,000 & \\
Travel time & \multicolumn{2}{c}{} \\
\hline
\end{tabular}

Notes: Significant when alpha was $<0.05$

Based on different test results (delta) treatments 1 and 2 using Mann Whitney test on gastrocnemius muscle strength, dorsiflexion flexibility and travel time, there was a significant difference, whereas there was no significant difference between treatment 1 and 2 in plantar flection flexibility

\section{DISCUSSION}

The results of this study showed that muscle strength in treatment 2 (control) had decreased by $2.12 \mathrm{~kg}$, whereas in flexibility dorso flexion and plantar flexion tended to remain, and travel time had increased by difference 0.23 seconds slower. The decrease in gastrocnemius muscle strength was due to muscle fatigue, high intensity exercise would require an increased energy consumption. Energy consumption was generated from aerobic capacity in cells, and the magnitude of ATP usage was broken down from anaerobic metabolic processes. Anaerobic metabolism would break down glycogen that could produce the intracellular concentration of hydrogen ( $\mathrm{IH}+$ ), and lactate ions, so that heavy exercise could decrease $\mathrm{PH}$, and increase lactate concentration in the body (Taylor \& Groeller 2008). In a 100 meter athlete the metabolism used predominantly used energies from ATP-PC. The use of this energy had a highly short duration due to the activity with high intensity, so it would produce high lactic acid (Foss et al 1998). In treatment 1 (experiment), the increase of gastrocnemius muscle strength with difference of $11.38 \mathrm{~kg}$, flexibility of dorsiflexion occurred an improvement with difference 
3.4600, plantar flexion flexibility increased by difference 3.4700 , while travel time had decreased by 0.19 second difference, describes faster travel time. This showed a significant effect with NMT administration, whereas when compared with the difference (delta) of treatment 1 and 2 only the plantar flection flexibility indicated a non-significant result.

NMT administration provided an enhanced muscle functional ability, stimulation of exteroseptive and proprioceptive neural systems. Exteroseptive stimulation in NMT would effect the reduction of blood stagnant and lymphatic fluid, improved local microcirculation, and absorption of edema by removing the skin that could cause the interstitial tissue space beneath it to be wider, increasing circulation and fluid absorption, so that subcutaneous pressure could be reduced, while proprioceptive stimulation was stimuli originating from muscles, tendons, aponeuroses, joint capsules, ligaments, and the stimulation of a condition of contraction or stretching. Both of these stimuli in both the exteroeptive and proprioceptive would provide stimulation to the central nervous system through the sensory nerve fibers, then would impulse the motor's response to the muscles, so that the response became better.

The NMT technique produced eccentric effects on the muscles that would increase elasticity and muscle length. When combined with the pull on the broad area of the skin, it would increase the extension/muscle length, fascia tissue, and skin, whereas there was no significant difference in plantar flexion flexibility due to the installation of NMT with decompression techniques that could have an eccentric effect on the gastrocnemius muscle, so that it tend to only increase the flexibility of dorsiflexion, whereas in plantar flection, it only gave a better motor response effect than without NMT (Blow 2012).

\section{CONCLUSION}

The provision of NMT (Neuromuscular Taping) has given better results than without using NMT on 100 meter sprinter athletes.

\section{REFERENCES}

Blow D (2012). Neuromuscular taping: from theory to practice, Milan, Edi-Ermes Medical Publisher.

Foss ML, Keteyian SJ (1998). Fox's physiological basis for exercise and sport, New York, The McGraw-Hill, p 35-36.

Hall JE, Guyton AC (2011). Guyton and Hall textbook of medical physiology 12th edition, Philadelphia, Saunders/Elsevier, p 601-613.

Harsono (1988). Coaching dan aspek-aspek psikologis dalam coaching, Jakarta, CV Tambak Kesuma.

Nala IGN (2011). Prinsip pelatihan fisik olahraga, Denpasar, KONI Bali.

Suharno HP (1993). Ilmu Kepelatihan Olahraga, Bandung, PT Karya Ilmu.

Taylor NAS, Groeller H (2008). Physiological bases of human performance during work and exercise, London, Churchill Livingstone. 